American Journal of Pharmaceutical Education 2017; 81 (2) Article 21.

\title{
VIEWPOINTS
}

\section{Flexner, Educational Reform, and Pharmacy}

\author{
Frank Romanelli, PharmD, MPH \\ University of Kentucky, Lexington, Kentucky
}

Across the academy, colleges and schools of pharmacy are scrambling to reimagine, recreate, modify, or completely overhaul their doctor of pharmacy (PharmD) degree curricula. This push to change has been termed in a variety of ways including but not limited to "educational renaissance," "curricular reform," "curricular transformation," and/or "curricular reengineering." Several factors have been implicated as drivers of these sometimes minor but often major changes to curriculum including the influence of rapidly evolving technologic advances, changes to the Accreditation Council for Pharmacy Education standards for the accreditation of PharmD programs, and evolutions in secondary and undergraduate education.

Pharmacy is certainly not the only health care profession dealing with change and curricular disruption. Many medical schools are moving to three-year accelerated programs and grappling with ever expanding bodies of medical research, the integration of the clinical and basic sciences, and the need to ensure that graduates have not only the knowledge but also the practical skill set necessary for the next stage of training or practice. Nursing and physical therapy programs have recently introduced clinical doctorates as either elective post-graduate options or entry-level degrees. Health care colleges across the spectrum are also managing mandates to increase both the quantity and quality of interprofessional education within respective curricula.

In 1910 Abraham Flexner first proposed some of the most widespread and pervasive changes to health care education when he argued that medicine should more strictly adhere to scientific principles and standards in both research and teaching. ${ }^{2}$ Interestingly, Flexner was not a physician, researcher, or medical educator but rather the product of a liberal arts education. He was born in Kentucky where he founded and operated a college preparatory school before he became engaged with the Carnegie Foundation. Despite a lack of health care training, Flexner was able to alter the course of medical education well beyond his 364-page 1910 report. Flexner's reach was not limited to medicine. In as early as 1908 , he criticized common teaching practices in his book The American College. He made a profound and perhaps foretelling statement when he wrote, "lectures enabled colleges to handle cheaply by wholesale a large body of students that would be otherwise unmanageable and thus give the lecturer time for research." 3

At my home institution, we have been engaged in a complete overhaul of our own PharmD curriculum. We are in the midst of launching the second semester of this reenvisioned degree program. As the class of 2020 continues to move from professional year to professional year, new courses will be taught and existing courses will become obsolete. In the interim our faculty members are conducting two concurrent curricula often referred to as "the old curriculum" and "the new curriculum." At this point in our trajectory, and after some serious reflection, it seems an appropriate time to take inventory of what we (I) have and have not learned:

- Change is hard. Hard for faculty, students, and staff. Despite common logic and opinion, it is even hard for those who are purposing or driving the change.

- Resistance is inevitable and may be a core trait of human kind. Despite altruistic or munificent intentions, there will always be resistance.

- Our peers are scholars who will question every intention. It is their right and duty to do so and it only brings credibility and reliability to the process.

- Mistakes will be made. Some things will be overlooked or forgotten. Paperwork will be compulsory and other unknown bureaucratic requirements will come to light.

- There will be times (maybe multiple times) when administrators, faculty, and/or staff begin to question if change itself was a mistake. This will require patience and a magnitude of resilience.

- Some interventions will work well while others will simply become known as "disasters." In any event, listen to anyone who is speaking. The key is seeing through the noise and trying to understand what is real and what is not.

- You will have to be willing to take some chances and possibly fail. In this regard, you must be willing to ask for feedback or criticism and learn from mistakes.

- A plan is better than a thought. A plan with deadlines is even better. A plan with deadlines and a commitment of resources is best. 


\section{American Journal of Pharmaceutical Education 2017; 81 (2) Article 21.}

- A new curriculum is a community project. It will take flexibility, commitment, and work from administrators to staff to students. Trying to leave one or the other behind can prove severely handicapping.

It is important to remember that Flexner was regarded as a reformer. His report was perceived by many as being overtly frank and hypercritical. However, Flexner possessed a clear educational (teaching) philosophy that served as the underpinning of his critiques and his moral compass. His report, which addressed almost every aspect of medical education from prerequisites to the education of women and minorities, might be required reading for anyone preparing to undertake a curricular overhaul. $\mathrm{He}$ was a very popular educator (even at the challenging secondary level), who prophesied learning through doing and problem solving rather than from simple rote memorization. ${ }^{4} \mathrm{He}$ was an unconventional choice to fight a significant battle on foreign terrain. Nonetheless, his relentless attention to task grounded in sound educational principles might still serve as a model to present day educators forced into the shoes of reformers.

\section{REFERENCES}

1. Blouin RA, Joyner PU, Pollack GM. Preparing for a renaissance in pharmacy education: the need, opportunity, and capacity for change. Am J Pharm Educ. 2008;72(2):Article 42.

2. Flexner A. Medical Education in the United States and Canada. A Report to the Carnegie Foundation for the Advancement of Teaching. Bulletin Number Four. Boston, MA: DB Updike, The Merrymount Press; 1910. http://archive.carnegiefoundation.org/pdfs/elibrary/ Carnegie_Flexner_Report.pdf. Accessed January 17, 2017.

3. Flexner A. The American College: A Criticism. New York, NY: The Century Company; 1908:215-216.

4. Duffy TP. The Flexner Report - 100 years later. Yale J Biol Med.s 2011;84(3):269-276. 